\title{
Notifikasi Email Sebagai Pengingat Pengembalian Buku Pada Perpustakaan Berbasis Website Terintegrasi Dengan RFID Dan QR Code
}

\author{
Tiara Putri Amanda ${ }^{1}$, Abdul Rakhman², Irma Salamah ${ }^{3}$ \\ 1,2,3Program Studi Teknik Telekomunikasi, Politeknik Negeri Sriwijaya, Jl. Srijaya Negara Bukit \\ Besar, Palembang, 30139 \\ tiaraputri3297@gmail.com, a_rahman_hamid@yahoo.com,irma.salamah@yahoo.com
}

\begin{abstract}
The library strives to maintain and improve efficiency and effectiveness in teaching and learning. Currently there are still many library services that use manual methods. Computerized service systems are able to streamline library services, so transactions such as searching, borrowing, returning and managing data can be done quickly and accurately. In this research, a website-based library service system is integrated with Radio Frequency Identification (RFID) as a library visitor identity card which can also be used when borrowing and returning books, and Quick Response Code (QR Code) is used as book identification. In this application the admin can process data, register books and members, borrow and return books, and view transaction reports. This application also provides e-mail notifications to resolve problems such as late returns to the loss of borrowed books. The notification automatically sends a message to the user to return the book on the last day of the loan. The existence of a service system in this website-based library application makes it easier for administrators in managing data, improving library services, and email notifications helps to remind the day of returning books.
\end{abstract}

Keywords: Library, Website, RFID, QR Code, Email

\begin{abstract}
Abstrak
Perpustakaan mengupayakan, memelihara dan meningkatkan efisiensi serta keefektifan dalam belajar mengajar. Saat ini masih banyak layanan perpustakaan yang menggunakan cara manual. Sistem layanan yang terkomputerisasi mampu mengefektifkan layanan perpustakaan, sehingga transaksi seperti pencarian, peminjaman, pengembalian dan pengelolaan data dapat dilakukan secara cepat dan akurat. Dalam penelitian ini dibuat sistem layanan perpustakaan berbasis website yang terintegrasi dengan Radio Frequency Identification (RFID) sebagai kartu identitas pengunjung perpustakaan yang juga dapat digunakan ketika peminjaman dan pengembalian buku, dan Quick Respon Code (QR Code) digunakan sebagai identifikasi buku. Pada aplikasi ini admin dapat mengolah data, melakukan pendaftaran buku dan anggota, melakukan peminjaman dan pengembalian buku, serta melihat laporan transaksi. Aplikasi ini juga memberikan notifikasi email untuk mengatasi permasalahan seperti keterlambatan pengembalian hingga hilangnya buku yang dipinjam. Notifikasi tersebut secara otomatis mengirimkan pesan kepada pengguna untuk mengembalikan buku pada hari terakhir masa peminjaman buku. Adanya sistem layanan pada aplikasi perpustakaan berbasis website ini mempermudah administrator dalam pengelolaan data.
\end{abstract}

Kata kunci: Perpustakaan, Website, RFID, QR Code, Email 


\section{PENDAHULUAN}

Teknologi dapat diterapkan di berbagai aspek kehidupan termasuk perpustakaan. Perpustakaan berperan untuk mengupayakan, memelihara dan meningkatkan efisiensi serta keefektifan dalam belajar mengajar. Perpustakaan dikatakan baik jika memberikan pelayanan dengan cepat, tepat dan akurat [1]. Setiap pengembangan layanan disesuaikan dengan kemajuan teknologi informasi dan komunikasi[2]. Sistem layanan yang terkomputerisasi mampu mengefektifkan layanan perpustakaan, sehingga transaksi seperti pencarian, peminjaman, pengembalian dan pengelolaan data dapat dilakukan secara cepat dan akurat. Pada penelitian sebelumnya, telah dibangun sebuah website sistem informasi perpustakaan [3]. Akan tetapi penelitian tersebut belum maksimal. Sistem belum menggunakan teknologi pendukung dan belum memberikan pemberitahuan kepada pengguna mengenai jadwal pengembalian buku.

Oleh karena itu, penulis mengembangkan aplikasi perpustakaan berbasis website yang terintegrasi dengan RFID dan QR Code. Aplikasi ini menjadi database yang mengelola data perpustakaan serta dapat melakukan transaksi peminjaman dan pengembalian buku. Terintegrasi dengan RFID (Radio Frequency Identification) sebagai kartu identitas pengguna dan QR Code (Quick Respon Code) sebagai objek identifikasi buku. Layanan ini juga memberikan notifikasi email kepada pengguna sebagai pengingat otomatis untuk mengembalikan buku pada hari terakhir peminjaman buku.

\section{METODOLOGI PENELITIAN}

Kerangka penelitian pada metodologi ini merupakan tahapan penelitian secara keseluruhan. Pada tahap pertama, melakukan perancangan QR Code yang digunakan sebagai label buku, memasukkan data mengenai informasi sebuah buku. Kemudian perancangan kartu identitas menggunakan RFID, sehingga setiap pengguna mempunyai kartu ini. Tahap kedua, melakukan perancangan aplikasi perpustakaan berbasis website dan menggunakan beberapa bahasa pemrograman. Tahap ketiga, integrasi aplikasi dengan RFID dan QR Code. Tahap ini menjadi tahap pengujian pada aplikasi tersebut. Kemudian pada gambar 2 merupakan flowchart sistem aplikasi yang mempunyai beberapa menu dengan proses dan fungsi masing-masing. 
Jurnal Riset Sistem Informasi Dan Teknik Informatika (JURASIK)

Volume (4) Juli 2019, pp 65-73

ISSN: 2527-5771/EISSN: 2549-7839

http://tunasbangsa.ac.id/ejurnal/index.php/jurasik

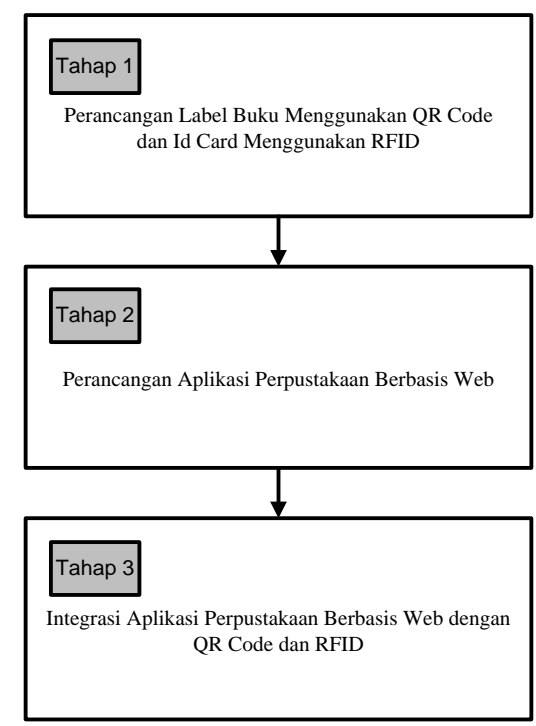

Gambar 1. Kerangka Penelitian

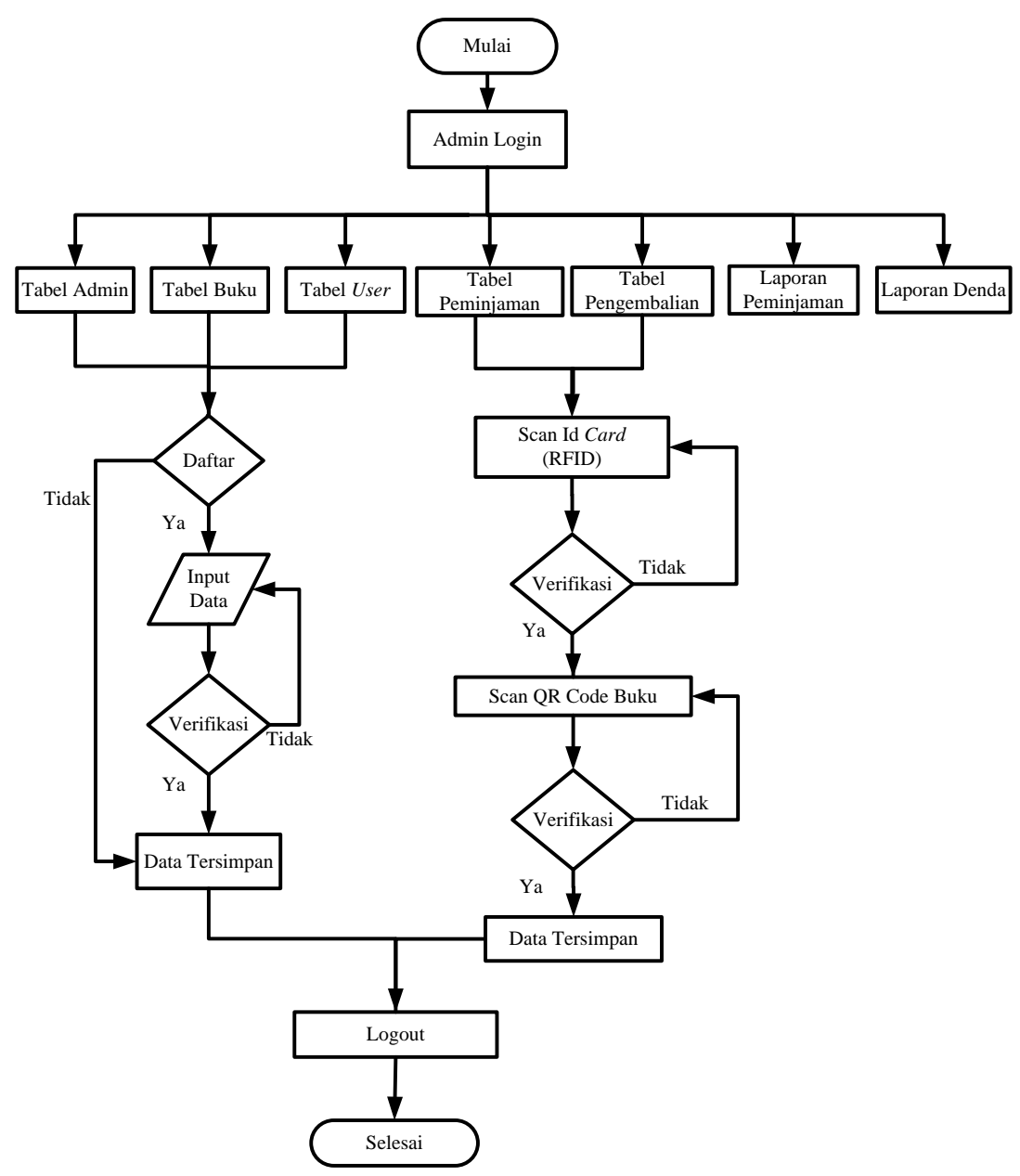

Gambar 2. Flowchart Sistem Aplikasi 


\section{HASIL DAN PEMBAHASAN}

\subsection{Hasil}

Perpustakaan berbasis website ini dapat diakses melalui http://www.telkom15.com/perpus/. Aplikasi ini memiliki beberapa menu seperti tabel admin, tabel buku, tabel user, peminjaman, pengembalian, laporan peminjaman dan laporan denda. Berikut adalah tampilan dari setiap halaman pada aplikasi:

a. Halaman Login

Halaman login merupakan tampilan awal aplikasi, dimana admin mengisi kolom NIP dan password untuk masuk ke halaman perpustakaan.

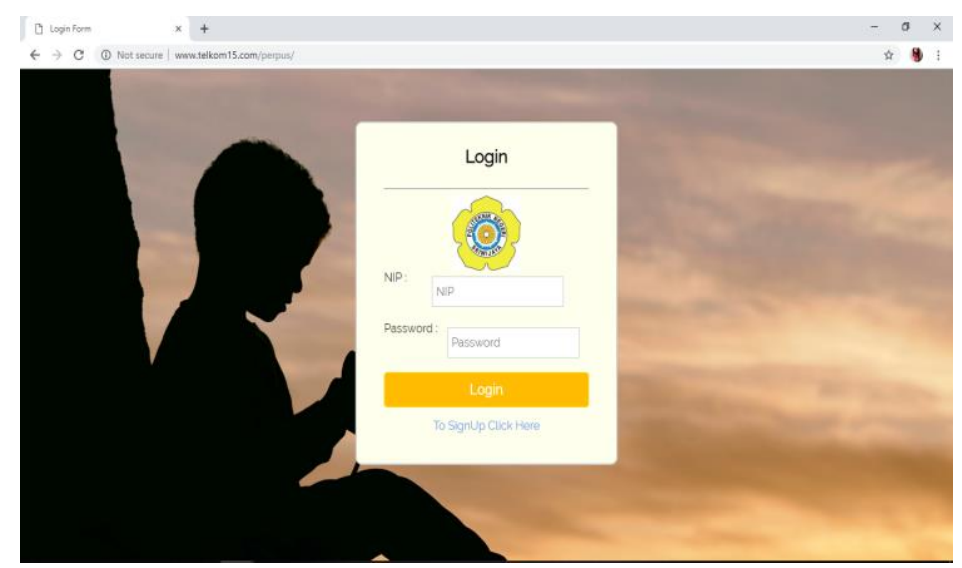

Gambar 3. Halaman Login

b. Halaman Tabel Buku

Beberapa koleksi buku ditampilkan pada menu tabel buku ini, berisikan informasi judul buku, nomor ISBN, pengarang, tahun terbit, dan jumlah. Jika ingin menambahkan data buku baru klik Tambah Data, kemudian jika ingin mengubah data atau menghapus data terdapat tombol edit dan delete pada kolom action. Pada halaman ini pengguna dapat melakukan pencarian buku dengan mudah dan cepat pada kotak search.

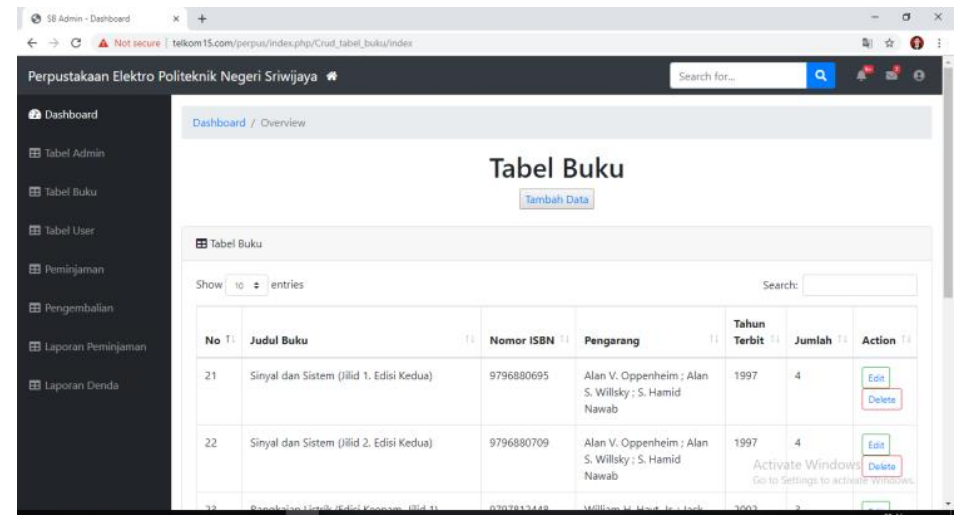

Gambar 4. Halaman Tabel Buku 
c. Halaman Tabel User

Jika ingin menambah anggota baru, klik menu tabel user lalu klik Tambah Data kemudian isi nama, nomor induk mahasiswa, tempat tanggal lahir, program studi, jurusan, tahun masuk, nomor hp, dan email. Setelah terdaftar, anggota baru akan mendapatkan id card yang menggunakan RFID sebagai identitas mereka. Kartu tersebut digunakan saat melakukan proses peminjaman dan pengembalian buku.

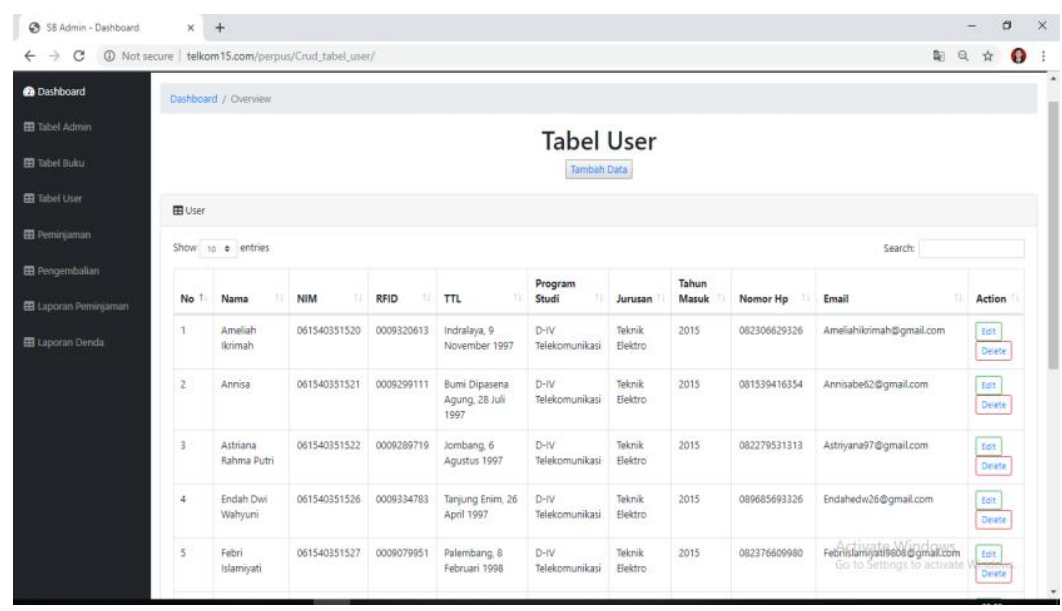

Gambar 5. Halaman Tabel User

d. Halaman Peminjaman

Menu peminjaman berisikan ID, nomor RFID anggota, nomor ISBN buku, tanggal peminjaman, tanggal pengembalian seharusnya, nama admin yang bertugas, dan status buku pinjaman tersebut. Tersedia juga tombol edit dan delete pada kolom action untuk mengubah dan menghapus data.

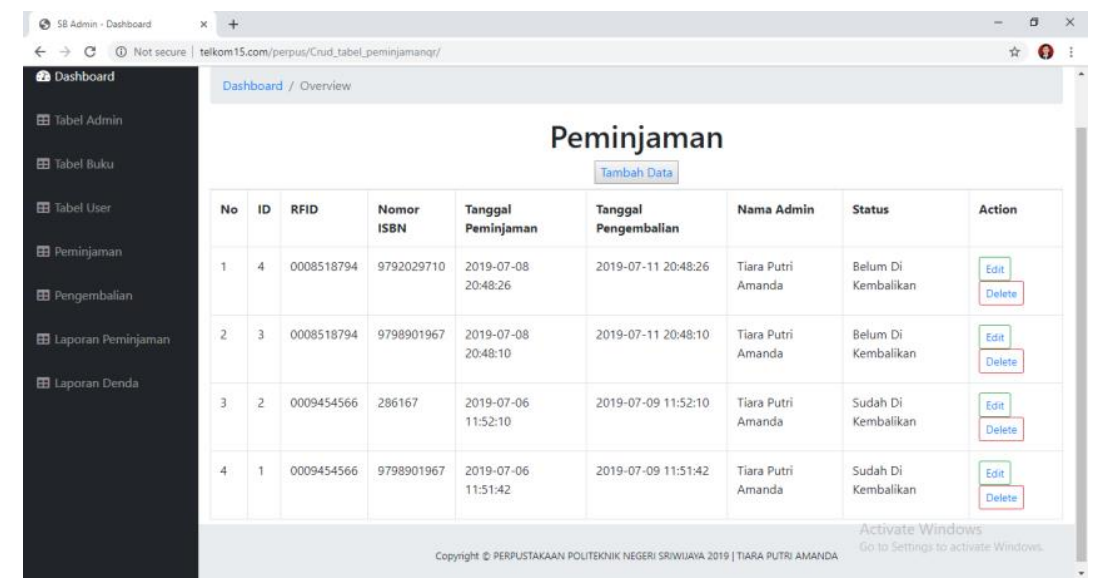

Gambar 6. Halaman Peminjaman

e. Halaman Pengembalian

Pada menu pengembalian berisi informasi pengembalian seperti ID, ID peminjaman, tanggal pengembalian, denda, nama admin, dan kolom action terdapat tombol edit dan delete untuk mengubah dan menghapus data.

Notifikasi Email Pengingat Pengembalian Buku Pada Perpustakaan (Tiara Putri Amanda) |69 


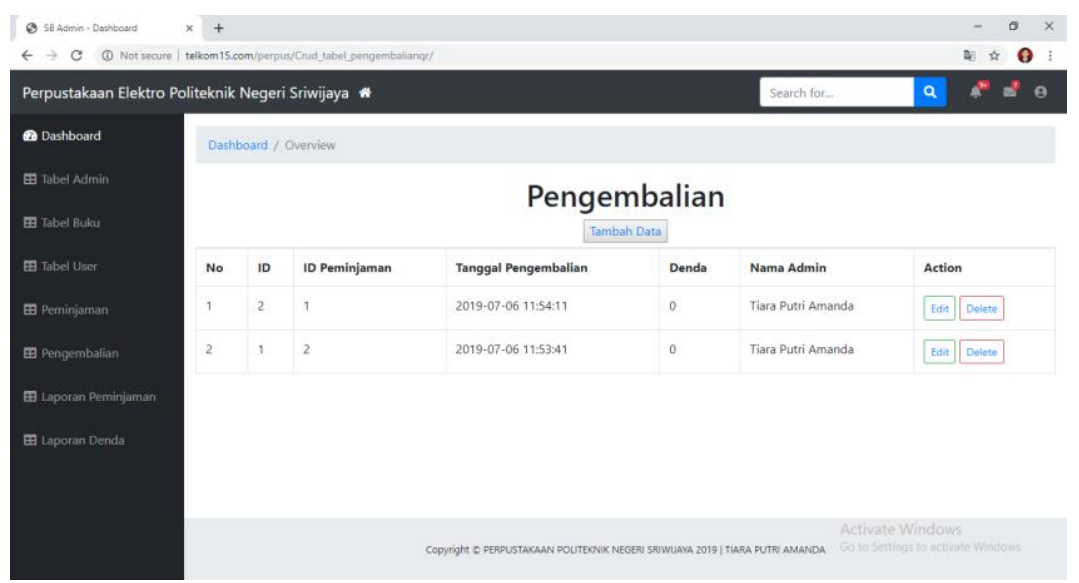

Gambar 7. Halaman Pengembalian

f. Halaman Laporan Peminjaman

Menu laporan peminjaman ini hanya menampilkan nama, judul buku, tanggal peminjaman dan status peminjaman baik belum dikembalikan atau sudah dikembalikan. Tersedia juga kolom search untuk membantu admin mencari data atau laporan dengan cepat, namun pada menu ini tidak tersedia kolom action agar tidak ada manipulasi data.

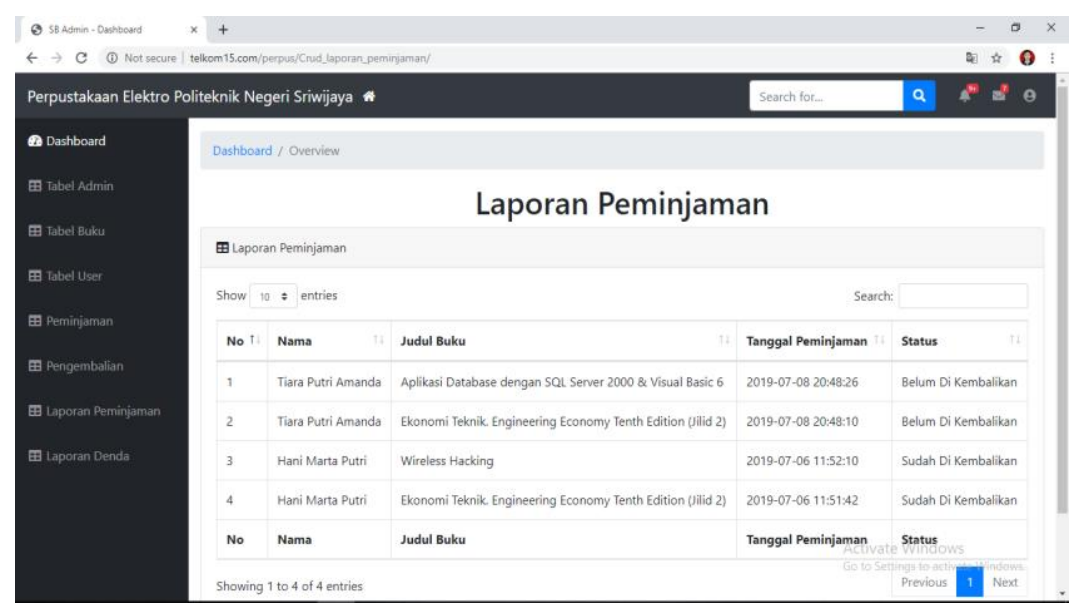

Gambar 8. Halaman Laporan Peminjaman

g. Halaman Laporan Denda

Menu laporan denda juga merupakan halaman laporan pengembalian yang menampilkan infromasi ID, ID peminjaman, nama, judul buku, tanggal peminjaman, tanggal pengembalian, denda, dan status baik sudah dikembalikan ataupun belum dikembalikan. Jika terlambat mengembalikan buku, anggota harus membayar denda yang telah ditentukan. 


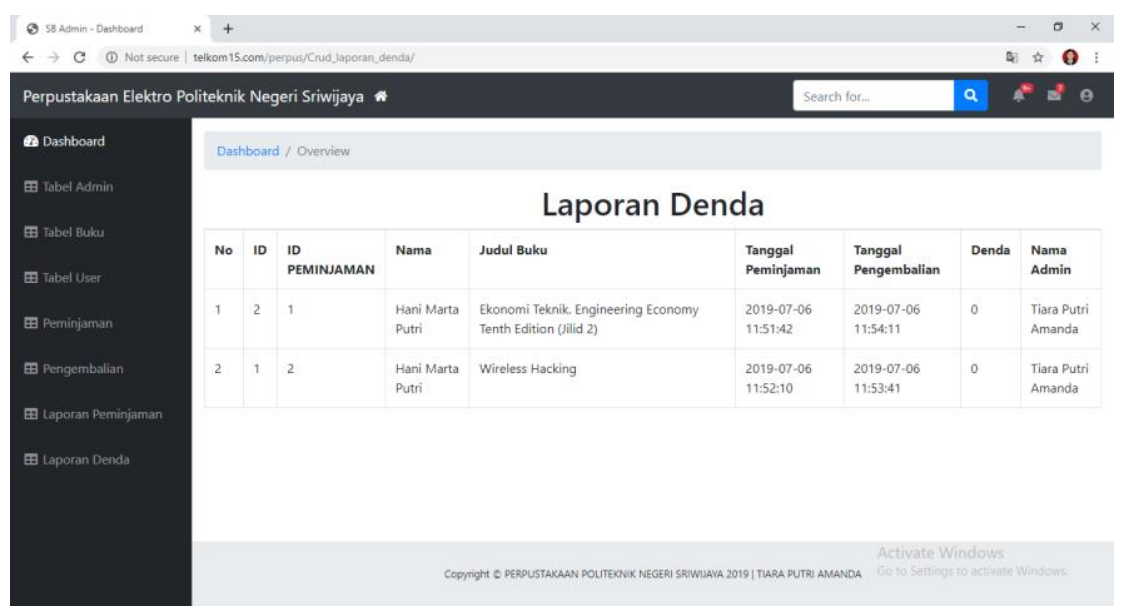

Gambar 9. Halaman Laporan Denda

\subsection{Pembahasan}

Jika ingin melakukan peminjaman buku, klik menu peminjaman kemudian pilih tambah data seperti gambar 5 . Adapun jika ingin mengembalikan buku, klik menu pengembalian kemudian pilih tambah data seperti gambar 6. Kedua transaksi tersebut memiliki proses yang sama yaitu pengguna scanning kartu identitas RFID pada RFID reader dan scanning QR Code label buku tersebut pada QR Code scanner. Berikut gambar perangkat keras pendukung aplikasi tersebut:

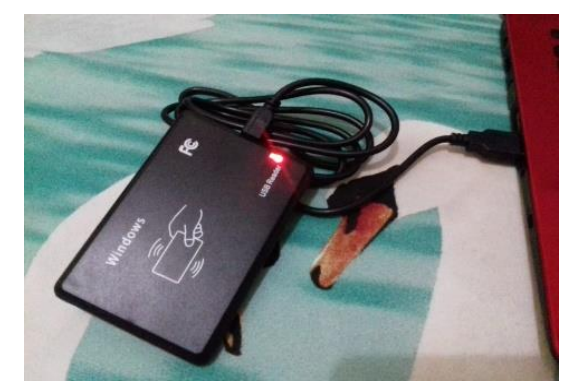

(a)

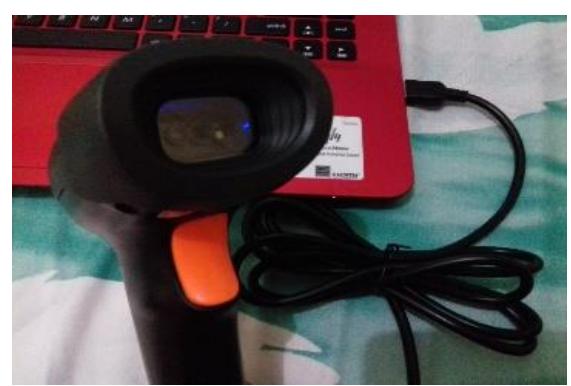

(b)

Gambar 10. (a) RFID Reader dan (b) QR Code Scanner

Kemudian untuk notifikasi email, sistem akan mengirimkan pesan untuk mengembalikan buku pada hari ketiga atau hari terakhir peminjaman secara otomatis kepada user. 


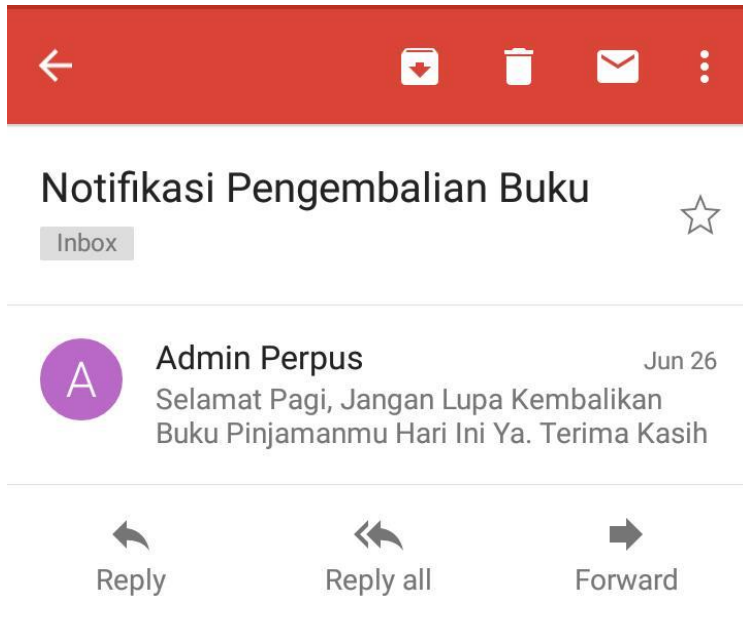

Gambar 11. Notifikasi Pengembalian Buku

Tabel berikut tabel hasil pengujian dari aplikasi perpustakaan berbasis website yang terintegrasi dengan RFID dan QR Code:

Tabel 1. Hasil Pengujian

\begin{tabular}{|c|l|c|c|}
\hline No. & \multicolumn{1}{|c|}{ Halaman yang Diuji } & \multicolumn{2}{c|}{ Hasil Pengujian } \\
\cline { 3 - 4 } & & Berhasil & Gagal \\
\hline 1. & Login & $\mathrm{V}$ & - \\
\hline 2. & Register & $\mathrm{V}$ & - \\
\hline 3. & Menambahkan admin pada Tabel Admin & $\mathrm{V}$ & - \\
\hline 4. & Menambahkan anggota pada Tabel User & $\mathrm{V}$ & - \\
\hline 5. & Melakukan transaksi peminjaman buku & $\mathrm{V}$ & - \\
\hline 6. & Melakukan transaksi pengembalian buku & $\mathrm{V}$ & - \\
\hline 7. & Notifikasi email (pada hari ketiga peminjaman buku) & $\mathrm{V}$ & - \\
\hline 8. & Tombol edit untuk mengubah data & $\mathrm{V}$ & - \\
\hline 9. & Tombol delete untuk menghapus data & $\mathrm{V}$ & - \\
\hline 10. & $\begin{array}{l}\text { Respon perangkat pendukung (RFID reader dan QR Code } \\
\text { scanner) pada proses peminjaman dan pengembalian buku } \\
\text { di aplikasi perpustakaan berbasis website }\end{array}$ & $\mathrm{V}$ & - \\
\hline
\end{tabular}

\section{SIMPULAN}

Penelitian ini merupakan perpaduan dan pengembangan dari penelitian terdahulu, yang mengintegrasikan RFID sebagai kartu identitas dan QR Code sebagai label identifikasi buku. Perpustakaan berbasis website ini mempunyai proses dan fungsinya masing-masing pada setiap menu dan diakses melalui http://www.telkom15.com/perpus/. Aplikasi ini menjadi database yang mengelola data perpustakaan serta dapat melakukan transaksi peminjaman dan pengembalian buku. Sistem layanan yang terkomputerisasi mampu mengefektifkan layanan perpustakaan, sehingga transaksi seperti pencarian, peminjaman, pengembalian dan pengelolaan data dapat dilakukan secara cepat 
Jurnal Riset Sistem Informasi Dan Teknik Informatika (JURASIK)

Volume (4) Juli 2019, pp 65-73

ISSN: 2527-5771/EISSN: 2549-7839

http://tunasbangsa.ac.id/ejurnal/index.php/jurasik

dan akurat. Layanan ini juga memberikan notifikasi email kepada pengguna sebagai pengingat otomatis untuk mengembalikan buku pada hari peminjaman buku.

\section{DAFTAR PUSTAKA}

[1] D. Ismail, Wardi, "Teknologi RFID Untuk Layanan Sirkulasi Perpustakaan Fakultas Ilmu Komputer Universitas Indonesia Timur," vol. 8, no. 1, pp. 16-25, 2017.

[2] “Undang- Undang Republik Indonesia Nomor 43 Tahun 2007 Tentang Perpustakaan," 2007.

[3] D. Hutagalung and F. Arif, "Rancang Bangun Sistem Informasi Perpustakaan Berbasis Web Pada Smk Citra Negara Depok," vol. 7, no. 1, pp. 13-22, 2018. 